\title{
Influence of Inspirational Motivation on Implementation of Human Resource Management Policies by Kakamega County Government, Kenya
}

\author{
Okoth Bonface Okoth \\ Doctoral Candidate, Institute of Postgraduate Studies, Kabarak University
}

\begin{abstract}
This study aimed to establish the influence of inspirational motivation on implementation of Human Resource Management policies by County Government of Kakamega. A descriptive research design and sample survey method involving use of questionnaire as the primary data collection instrument was adopted. The study population was 6,328 County Government of Kakamega employees. Simple random sampling technique was applied to get a sample size of 154 respondents with a pilot study being conducted in Bungoma County where the study checked for internal consistency and reliability of the instrument for data collection. Cronbach's coefficient alpha of 0.867 was obtained for internal reliability. Ethics governing research were accorded utmost consideration. A 92.7\% return rate was attained, good for social statistics analysis. The Statistical Package for the Social Sciences (SPSS) was used to analyze data in the study. Pearson Product Moment Correlation Coefficient and linear regression were used in analysis within $95 \%$ confidence interval to test for associations, relationships and independence of indicators. Study findings revealed a significant and positive relationship between inspirational motivation and implementation of Human Resource Management Policies. Based on the study findings, it was concluded that inspirational motivation as a construct of transformational leadership had a significant positive influence on implementation of Human Resource Management policies at Kakamega County Government. The study therefore stretches the frontiers of knowledge on the nexus between transformational leadership and implementation of Human Resource Management policies and recommends the adoption of Human Resource Management practices that harness the benefits of transformational leadership at the work places not only at the County Government of Kakamega but in all public and private organizations in Kenya and beyond.
\end{abstract}

Keywords: Idealized Influence, Implementation, Human Resource Management Policies

DOI: $10.7176 / \mathrm{JRDM} / 75-05$

Publication date:May $31^{\text {st }} 2021$

\subsection{Background of the Study}

The origins of the concept of public service motivation go back to an article published by Rainey in 1982 in which the author investigated the behavior of middle managers of four public and four private organizations in order to understand if there were differences in the intrinsic and extrinsic attitudes and motivations of individuals. The results of the study showed that public managers were statistically more sensitive to the issues related to public service compared to private managers. Therefore, even without explicitly talking about public service motivation, Rainey (1982) put forward the idea that the motivational levers of public and private employees are different: the former, in particular, are particularly attracted to motivations related to public interest.

In India, literature review of scholarly articles on leadership in Indian organizations shows that some recent leadership research has focused on testing universal charismatic and transformational leadership theories (Giri and Santra, 2010; Singh and Krishnan, 2007). On the other hand, there are studies conducted by Indian researchers who have developed indigenous leadership model and theories. Sinha (1980) developed a culturally contingent leadership model, the nurturant-task leadership model, which has been tested and found to be extremely relevant in Indian context. Sinha (1995) presented evidence from more than 40 field studies showing support for the effectiveness of the nurturant-task leadership style in Indian context. Nurturant-task leadership model has been tested in some recent empirical studies conducted in Indian organization (Palrecha, 2009; Sayeed, 2010; Suar et al., 2006). Another study by Singh and Krishnan (2007) used a combination of qualitative and quantitative methods to develop a new scale to measure Indian transformational leadership. Studies conducted by Singh and Bhandarker (2011) used mixed research methodology and explored the construct of transformational leadership as "Change Maestros" (2011) in the Indian context. Singh and Bhandarker (2011) have posited basic competencies such as contextual sensitivity, compelling vision and purpose, winning streak, people connect and engagement, meaning making, contribution focus, speed, creative destruction as defining feature of change maestros. An extensive literature review of leadership studies suggest that positive traits of leaders have been given a lot of importance by Indian leadership researchers (Kanungo and Misra, 2004; Singh and Bhandarker, 1990; Sinha, 1995). In the course of developing a scale to assess transformational leadership in Indian context Singh and Krishnan (2007) identified positive dimensions of leadership (performance-oriented and humane, 
openness and nurturing, sensitive and conscientious, personal touch, conviction in self and non-traditional). Comparisons of the leadership attributes emerging in Indian studies discussed above seem to suggest that some aspects of positive leadership overlap with transformational leadership theme. It appears that there was a need to re-conceptualize the transformational leadership theme in line with the current scenario and practices.

Since 1982, many studies have been published concerning the definition, measurement and implications of public service motivation. Despite this, the theoretical framework still needs to be deepened and investigated (Valotti et al., 2010). Perry and Wise (1990) provided the first definition of public service motivation as "an individual's predisposition to respond to motives grounded primarily or uniquely in public institutions and organizations" (p. 368). This concept born from and assumes the failure of ten years of employees' remuneration linked to the results in the US Government, the existence of a public service ethic that had long been reaffirmed by researchers and the lack of a systematic research on the issue of motivation for public workers.

In particular, the concept of public service motivation is based on the idea that the reasons that push people to act, commit themselves, guide choices, organizational efforts and behaviors are different depending on the sector in which these subjects operate, differentiating between the public and the private sector (Crewson, 1997). Perry (2000) identified four dimensions that determine the public service motivation: attraction to policy-making (basing on the desire to satisfy one's personal needs while also serving the community), commitment to the public interest (representing the altruistic desire to serve public interests), compassion (including love for others and the desire to make them feel protected) and self-sacrifice (providing services for other people, renouncing at tangible personal incentives).

Public service motivation has been studied with reference to the antecedents that determine it; Perry (1996) proposed to investigate the effect of educational and organizational influences on public service motivation, Wright (2004) found that slightly more than half of the variance of motivation at work can be explained by the specificity and difficulty of objectives, while Bright (2005) proposed that public service motivation is strongly linked to gender, educational level, hierarchical level and individual preferences regarding monetary incentives. Other authors also focused on some other determining variables. For example, Camilleri (2006) proposed that the perception employees have of their organization influences their emotional and regulatory commitment and these, in turn, have a direct effect on public service motivation. The subsequent year, Camilleri (2007) confirmed that the organizational context (characteristics of work, relationships between employees and managers, perceptions that employees have of their organization) is the most important predictor of public service motivation of public employees and, still, Camilleri (2009) also noted that public service motivation is influenced by employees' perceptions of the remuneration and promotion policies used and promoted in their organization. Grant (2008) proposed that public service motivation of employees can be strengthened by showing them the benefits it produces for users. Furthermore, Jung and Rainey (2009) noted that specific roles, a clear organizational mission, a high commitment to the objectives and a high perceived relevance of these objectives increase the likelihood that public employees will declare themselves motivated in performing their duties. Finally, Paine (2009) stated that religiosity, family patterns, professional identification, political ideology and age are the main predictors of the public service motivation.

All these studies affirm the importance of this construct for the performance of public workers and refer to organizational variables and personal characteristics to explain the behavior of individuals. The problem, however, is that in the public sector there are not the same motivational levers than in the private sector. In order to motivate an employee in the private sector it is possible to offer him career surpluses or a higher salary, but this type of motivation is not applicable to the public sector due to structural and moral reasons. As mentioned, the basic hypothesis of public service motivation is that the desire to help others and achieve the common good are stronger motivational levers in the public sector than in the private one; in other words, the factors that move personal interest and are the driving force of organizational action in the public sector are more oriented towards intrinsic factors, while private employees are more motivated by extrinsic factors (Steijn, 2008). For example, the ability of a public organization to influence the quality of life of citizens can be an important motivational factor while, on the contrary, the introduction of monetary incentives in the sphere of a performance management system would have a less significant impact on the public than on the private sector, where the extrinsic motivational component is stronger (Galdiero and Pezzillo Iacono, 2018). For this reason, it is possible that there are some contextual factors that turn the behavior of individuals in the opposite direction, and one of these could be a context of change. Given that public service motivation is based on the values of the institutions, in the case of frequent changes and turnovers in political coalitions it is likely that public workers are unable to identify themselves in the majority coalition and, therefore, are not encouraged to carry out their tasks in the better way.

As already mentioned, the Italian context is characterized by the continuous change at the political summit (Mele and Ongaro, 2014) and by the spoils system that determine a very peculiar context: public managers must constantly interface with new people which, from time to time, set different objectives and working methods, not allowing an organizational or a task continuity. These sudden and constant changes could, therefore, demotivate 
employees in the performance of their activities.

It is important that transformational leaders know how to handle this probable cause of inefficiency in the public administration, since an unmotivated individual will be less likely to achieve positive performance. A first task of transformational leaders should therefore be to make their collaborators appreciate the values of new political forces: although not in continuity between them, it is possible that employees can appreciate new ideologies and make them their own, in order to experience greater public service motivation. Furthermore, another motivational lever could be that of creating organizational structures that do not depend on turnover and on frequent changes in the public administration that is to ensure the functioning of the structure that can be as separate as possible from the political powers from which it is represented. Finally, a transformational leader could leverage on the personal characteristics of individuals, since literature has shown how these variables are cornerstones for this theory, in order to increase public service motivation even in times of change.

Human Resource Management policies are continuing guidelines on the approach an organization intends to adopt in managing its people. They define the philosophies and values of the organization on how people should be treated (Armstrong, 2006). HR policies therefore serve as reference points when employment practices are being developed and when decisions are being made about people. As distinguished by Saetren (2005), HR policy provides generalized guidelines on the approach adopted by the organization and therefore its employees, concerning various aspects of employment. On the other hand, a procedure spells out precisely what action should be taken in line with the HR policy. HR are the set of individuals who make up the workforce of an organization. The term is also used to describe the function within an organization responsible for implementing policies related to the management of employees (May, 2003). Katou (2008) affirms that HR are the only strategic weapon a company has that cannot be copied by its competitors, hence the success of an organization depends upon competent, motivated and satisfied employees (O'Toole, 1995).

In any organization, Human Resource Management policies are the basis of optimal operations, management employees' job satisfaction and performance (winter, 2003). As examined by Armstrong (2006) Human Resource Management policies covers equal opportunity, managing diversity, age and employment, promotion, work- life balance, employee training and development, reward, discipline, involvement and participation, employee relations, new technology, health and safety, grievances, redundancy, sexual harassment, bullying, substance abuse, smoking, AIDS and e-mails. Other important policies according to Brinkerhoff and Crosby (2002) include disability accommodation, probationary period, personnel data and management of personnel files, compensation and benefits; policies which cover information on salary scale or the rationale for determining salaries and conditions for pay increases. Benefits include vocation, holiday, sick leave, bereavement leave, leave without pay, maternity and paternity leave and injury on duty.

Similarly, Mazmanian and Sabatier (1989) reported that additional HR policies are workers' compensation insurance, death benefits, pension/ retirement plans, use of office equipment and internet, safety transportation, telecommuting, business meals or entertaining clients, professional development benefits, termination pay and bonuses, among others. Armstrong (2006) emphasized that Human Resource policies help to ensure that when dealing with matters concerning employees, an approach in line with corporate values is adopted throughout the organization. They serve as basis of enacting values. They provide frameworks within which consistent decisions are made and promote equity in the way in which people are treated, hence facilitate empowerment, devolution and delegation.

\subsection{Statement of the Problem}

Implementation of policies by governments and organizations in developing countries is an issue. Implementation is the gap that exists between policy intent and outcomes; service delivery (Mazmanian, 1989). In South Africa, Hanekom and Sharkansky (2009) confirmed the relationship between political leadership and policy implementation. Despite the requirements by Kenyan Constitution (2010), implementation of Human Resource Management policies by Kakamega County government has not been properly achieved. Researchers have generally supported the position that transformational leadership influences implementation of Human Resource Management policies. Empirical evidence supports existence of a relationship between transformational leadership and policy implementation (Amanya \& Rebecca, 2006; Buabeng, 2005). Only a limited number of studies have so far examined the influence of transformational leadership on implementation of Human Resource Management policies in the context of Kenya. A study by Datche (2015) suffered a contextual gap given it explored Kenyan state corporations that were long established organizations compared to Kakamega County government which was only six years old. The limited nature of research in this area and lack of empirical evidence on the link between transformational leadership and implementation of Human Resource Management policies by Kakamega County government suggests the need for further investigation. Therefore, the aim of this study is to deepen the knowledge on the subject by identifying how inspirational motivation influences implementation of Human Resource Management policies. 


\subsection{Study Objective}

To establish the influence of inspirational motivation on implementation of Human Resource Management policies by Kakamega County Government, Kenya.

\subsection{Research Hypothesis}

Inspirational motivation does not have a statistically significant influence on implementation of Human Resource Management policies by County Government of Kakamega

\subsection{Literature Review}

One of the main factors that influence good governance is the role of leadership. Leaders motivate individuals to achieve their targeted goals (Northouse, 2015). Syed et al. (2012) found that the concept of leadership is not well understood in developing countries. A lot of basic characteristics that are essential for effective leadership in the public sector are still absent. Recently, it seems that leaders face other challenges, citizens have rapidly viewed the activities of public sector leaders through increasing levels of public awareness and the widespread of social media (Ceron, Curini, Iacus, \& Porro, 2014; Madge, Meek, Wellens, \& Hooley, 2009).

Understanding leader behaviors, particularly in the public sector, is a critical and vital issue. In fact, publicsector leaders present an essential role towards achieving high levels of good governance elements (Atkins, 2008; Masud, 2013). On the one hand, despite having some general thoughts on relying on bureaucracy in the government sectors, some researchers found that improvement in organizations depends first and foremost on leadership type and behaviour (Islam, 2010). On the other hand, scholars found that transformational leadership is at least as common and useful in the public sector (Dumdum, Lowe, \& Avolio, 2002; Wright \& Pandey, 2009). There is a growing emphasis on the practice of transformational leadership as a way to understand how leaders play a significant role in building organizations, and influencing the elements of good governance (Masud, 2013; Mohamad et al., 2014). A full range of leadership here introduces the four elements of transformational leadership.

Van der Voet (2014) identified in transformational leadership a fundamental variable to face the processes of change with the aim of motivating and stimulating employees in working activities within the organizations. Karp and Helgø (2008) suggested that public managers act as effective leaders in changing contexts when they influence the patterns of human interactions, paying attention to people, identity and relationships. Because of the unpredictability of the organizational and administrative environment, many times the reasons for change are not clear also for managers, who are likely to experience a feeling of uncertainty and instability, with relevant consequences on their work.

Authors studied the effects of transformational leadership on public service motivation. Moynihan et al. (2009) hypothesized the presence of a direct and positive relationship between this kind of leadership and public service motivation, so, in a context of change, public managers can focus on this lever to obtain results linked to the value of the public mission; Park and Rainey (2008) have shown that transformational leadership and public service motivation have a strong positive correlation with job satisfaction, performance and quality of work and a negative correlation with turnover intention; finally, Paarlberg and Lavigna (2010), based on a review of the literature, proposed a new framework that links transformative leadership, person-organization fit, socialization, work environment, goal-setting theory and self-determination theory with public service motivation (Valotti et al., 2010).

Transformational leaders try to influence their followers through inspiring their visions, modelling their way, enabling the subordinates to challenge the way and to act, and to encourage the heart. In practicing transformational leadership managers usually meet stressful situations (Bass, 2014; Bennis and Nanus, 2015; Karina et al., 2008). Work-related stress remains a significant problem in many countries. For example, in Great Britain, it accounts for around a third of all new cases of work-related ill health. In total, an estimated 10.5 million working days were lost in Great Britain to work-related stress, depression and anxiety in the financial year 2005/06 (HSE, 2006). During that period, an estimated 420,000 reported that they were suffering from work-related stress to an extent that they became very ill. There is a general untested expression that stress levels among senior workers in the civil services of many developing/emerging economies are very high. But the fact remains that stress has ill effects on the individual, businesses, productivity and performance levels, and organizational image and reputation.

\subsubsection{New Public Management Theory}

The new public management theory was proposed by Hood (1991) who stated that to reconfigure the state along more cost- efficient (and effective) lines required new public management approaches. He further affirmed that the public sector be opened up to greater private sector influence. Besides, Balk (1996); Hughes (2014) and Mongkol (2011) insisted that the new public management reforms were aimed at improving the quality of public services, saving public expenditure, increasing efficiency of governmental operations and most importantly, making policy implementation more effective. Additionally, Barbuto (2005) emphasized that the theory 
represents a set of ideas, values and practices aimed at emulating private sector practices in the public sector.

So, Andrews (2012) proclaimed that large and monopolistic public bureaucracies are inherently inefficient and this was the critical force driving emergence of the new public management theory. Bourgon (2007) revealed that the three underlying issues which new public management theory attempts to resolve are: citizencentered services, value for tax payer's money and a responsive public service work force. He further observed that the theory takes its intellectual foundation from markets, productivity and managerialism; focusses on management approaches to achieve productivity gains. As well, the theory was supported by Zungura, (2014) who justified that the dominant theme of new public management is the use of market techniques to improve performance in the public sector. Eminently, the broad idea of new public management theory, is the use of market mechanisms in the public sector to make managers and providers more responsive and accountable (Hughes, 2014; Mongkol, 2011).

This study will draw from the theory of new public management in understanding the influence of Transformational Leadership on implementation of Human Resource Management policies by Kakamega County government. The theory is important in understanding effective policy implementation which results in service delivery. The objective of establishing county governments and Kakamega County in particular, is to ensure efficient service delivery. In this regard, Kakamega County government is an important target for new public management reforms in improving policy implementation that translates into quality service delivery and increased efficiency of governmental operations.

\subsubsection{Empirical Literature Review}

Empirical literature review is a directed search of published works that discusses theory and presents empirical results that are relevant to the topic at hand (Dvir, Eden, Avolio \& Shamir 2002). Empirical literature review is a comprehensive survey of previous studies related to a research question, narrowly tailored, addressing only the inquiry that is directly related to the research question (Feinberg, Ostroff \& Burke, 2005). According to Wagana, (2017), through the use of a systematic approach to previous scholarship, empirical literature review allows a researcher to place his or her research into an intellectual and historical context. Fundamentally, empirical literature review helps the researcher declare why their research matters. In this study, the empirical literature review discusses previous studies that are relevant in examining the relationship between transformational leadership and policy implementation based on identified variables.

For a long time, the relationship between transformational leadership and organizational performance has been analyzed in literature (Bass, Avolio, Jung \& Benson, 2003). Meta- analyses show a positive relation between transformational leadership, organizational leadership and organizational performance (Lussier \& Achua, 2004). These results hold different organizational contexts and different group success criteria such as group performance (Nielsen, Randall, Yakar \& Brenner, 2008), project success in R\&D departments and innovation (Shin \& Zhou, 2003).

Meta-analyses and reviews have evidenced the positive effects of transformational leadership on both team and organizational performance (Dumdum, Lowe \& Avolio, 2002). According to Northouse, (2010) transformational leadership accounted for 28.5 percent of the total explained variance in group performance and 22.8 percent of the explained variance in leader effectiveness. Saboe, Taing, Way and Johnson (2015) conducted a study on the unique mediators that underline the effect of different dimensions of transformation leadership by looking at two dimensions of idealized influence and individualized consideration on follower and organizational outcomes. The findings indicate that the dimensions of transformational leadership operate through unique channels. Kala (2014) conducted a study on the relationship between leadership styles and employee engagement using 150 employees from diverse sectors in Coimbatore. The study concludes that leadership styles influence employee engagement and has significant relationship with all the factors in the job engagement. Specifically, transformational leadership was found to be significantly related to employee engagement.

Ghafoor, Qureshi, Khan and Hijazi (2011) studied transformational leadership, employee engagement and performance among 270 employees and managers of telecom companies in Pakistan. His findings indicated significant relationship between transformational leadership, employee engagement practices and employee performance. The results also supported the mediation of psychological ownership in relationship of these variables. Riaz and Haider (2010) studied the link between supervisors' transformational leadership and staff nurses' extra role performance as mediated by self-efficacy and work engagement. A direct relationship between transformational leadership and work engagement was found.

Barbuto Jnr (2005) investigated the relationship between leaders' motivation and the use of charismatic, transactional and transformational leadership and the study findings revealed that inspirational motivation, idealized influence and individualized consideration range $(r=.10$ to .29) for self-reports while rates inspirational motivation, idealized influence and individualized consideration $\mathrm{r}=.18$ to .19. The role work engagement and performance play in staff retention has received considerable attention in both nursing and management literature. Researchers have found significant relationships between work engagement, job satisfaction, job performance and retention (Hope, 2012, Schauffeli \& Salanova, 2007). 
Markos and Sridevi (2010) in their work, employee engagement: the key to improving organizational performance found that employee engagement is a stronger predictor of organizational performance clearly showing the two-way relationship between employer and employee compared to the three earlier constructs of job satisfaction, employee commitment and organizational citizenship behaviour (OCB). They found out that engaged employees are emotionally attached to their organizations and highly involved in their job with great enthusiasm for success of their employer, going extra mile beyond the employment contractual agreement.

Hughes (2014) determined the importance of transformational leadership in the social sector. He concluded that transformational leadership is an effective strategy to employ in social sector and is one of the most prevalence common threads amongst high impact non-profit organizations. In Poland, another study by Ann and Kotarba (2015) was carried out to empirically examine leadership style, political interest and rationality of municipal executive bodies in the implementation of public policies. The study found that there exists a significant relationship between leadership style and implementation of public policies. Transformational leadership values and competences have an important role in achieving health system that fosters community well-being and basic care for all. Newer concepts argue that client satisfaction cannot be achieved without adoption of transformational leadership behaviour and practical application of intellectual stimulation.

This leads to new ways of improving the situation and enhancing productivity of health professionals by virtue of its professional competency, innovation, creativity, knowledge and skills that in turn results in client satisfaction (Avolio, Waldman and Yammarino, 1995). Pradeep and Prabhu (2011) conducted a comparison between selected public and private sector enterprises with the aim of exploring the relationship between transformational, transactional and Laissez fair leaderships and employee performance through correlation and regression analysis. The results indicated that transformational leadership style has significant relationship with performance outcome. Additionally, Crompton (2012) examined the effects of mentorship on Small and Medium Enterprise's performance and growth. Findings establish linkages between mentorship and employees' level of confidence and identified that mentorship as an antecedent to employee level of confidence (self-efficacy), is a non- direct influence of firm performance and growth.

\subsubsection{Inspirational Motivation and Implementation of Human Resource Management Policies}

Inspirational motivation puts a vision that inspire and motivates employees (Koech \& Namusonge, 2012). Inspirational motivation leadership refers to leaders who have the ability to inspire and motivate followers. They constantly challenge followers to higher levels of performance. According to Bono and Judge (2004), these leaders have a strong vision for the future based on values and ideals. Here the leader articulates a vision that is appealing and inspiring to followers. Furthermore, Kelly (2005); Stone, Russell \& Patterson (2003) stated that through the vision, the leader offers to followers the opportunity to see meaning in their work. Over and above that, followers are challenged with high standards and the leader encourages them to become part of the overall organizational culture and environment. As well, Barbuto (2005) proclaimed that due to inspirational motivation, followers are willing to invest more effort in their tasks, feel encouraged and optimistic about the future and believe in their abilities.

Inspirational motivation can be achieved through motivational speeches and conversations by the leader and other public displays of optimism and enthusiasm highlighting positive outcomes and stimulating teamwork (Simic, 1998). In addition, the supervisor is optimistic and enthusiastic about the future. This leads to follower commitment and contributions to their organization (Bomo \& Judge, 2004). Equivalently and most importantly, idealized influence and inspirational motivation are strongly related and are sometimes combined to form a measure of charisma (Bass \& Avolio, 1995).

\subsection{Research Design and Methodology}

The methodology employed in the study is described below;

\subsubsection{Research Design}

Further, Bryman and Bell (2007) aver that research design is the blue print for collection, measurement, analysis of data and a plan to obtain answers to research questions. Similarly, research design is a plan or framework for data collection and its analysis which reveals the type of research (Cooper \& Schindler, 2006). Essentially therefore, research design is a plan of how the research was carried out. A Descriptive research design and sample survey method involving use of questionnaire as the primary data collection instrument was adopted.

The study focused on Kakamega county government because it was a pace setter among the 47 county governments in Kenya. That was exhibited by the higher rate of development, minimum complaints from the public about service delivery and peaceful county government operation systems. It was against that exemplary performance that His Excellency, Mr. Wycliffe Oparanya was elected chairman of the council of governors in the republic of Kenya so as to share his transformational leadership experiences with other governors.

Population of the study comprised of all the 6,328 employees of Kakamega County government in the following categories; 13 county executive committee members, 90 members of county assembly, 12 sub county administrators, 18 county chief officers, 35 county directors, 89 county assembly staff and 6,071 county 
executive staff.

The target population was stratified into various categories to enable collection of data. The categories of officers from Kakamega County government involved in the study included: county executive committee members, members of county assembly, sub county administrators, county chief officers, directors, county assembly staff and county executive staff. Simple random sampling procedure where every officer had equal chance of representation was used in each stratum of the study to get respondents.

A sample size of $20 \%$ to $25 \%$ is representative enough of the target population and that findings obtained from such a sample can be generalized to the population of the study (Kothari \& Garg, 2014). The study sampled 154 respondents from the study population.

This study relied on questionnaires in the collection of data. The questionnaire was prepared by the researcher under guidance of university supervisors.

\subsection{Research Findings}

Table 1: Test for Normality in data distribution for the study

\begin{tabular}{|l|l|l|c|}
\hline & \multicolumn{3}{|c|}{ Shapiro-Wilk } \\
\hline Variables & Statistic & \multicolumn{1}{|c|}{ Df } & Sig. \\
\hline Inspirational motivation & .857 & 45 & .001 \\
\hline
\end{tabular}

a. Test statistic is normal

b. Test statistic is uniform

$\mathrm{N}=154$ listwise

The test resulted in significant results, indicating that the data for this study was normally and uniformly distributed. This is shown by a coefficient above 0.5 with $\mathrm{p}$ values less than 0.05 . Such normal and uniform distribution made it safe for the researcher to use statistical procedures that assume normality and uniformity in data distribution such as regression analysis and Correlation.

\subsubsection{Demographic Characteristics of Respondents.}

The study was interested with the demographic of the respondents that constituted the targeted sample within the employment ranks in the county government. The county government's organizational layout presents the characteristics of the corporations that participated in the study. In the study, the following factors were considered relevant when choosing from demographics that explained the population under study; the factors were studied considering their frequencies and percentages, they include the following;

Table 2. Frequency distribution for gender of respondents

\begin{tabular}{lcc}
\hline Category & Frequency & Percent \\
\hline Male & 100 & 64.9 \\
Female & 54 & 35.1 \\
Total & 154 & 100.0 \\
\hline
\end{tabular}

Findings indicated that majority among respondents in the study were employees of the masculine gender represented by $64.1 \%$ (100) and their female compatriots were $35.1 \%$ (54) in number. These findings coincide with various researchers whose studies on the differences in group-processes due to gender. Women are characterized as being relatively submissive and passive and they possess "feminine traits," e.g., they are kind and selfless whereas men are aggressive and independent (Feather, 1984). Women place less emphasis on competitive success and more on doing tasks well and promoting harmonious relationships (Betz, O’Connell, \& Shephard, 1989).

Also, the study was interested in their age brackets that also related to their experiences working within such organization and the following were the findings;-

Table 3. Frequency distribution of respondents' age bracket

\begin{tabular}{lcc}
\hline Category & Frequency & Percent \\
\hline $18-25$ years & 6 & 3.9 \\
$26-35$ years & 6 & 3.9 \\
$36-43$ years & 72 & 46.8 \\
44 - 55 years & 70 & 3.9 \\
Total & 154 & 100.0 \\
\hline
\end{tabular}

Findings revealed a majority among respondents being employees whose ages fall between 36 - 43 years that were represented with $72(46.8 \%)$ followed by those within 45 - 55 years that were represented by 70 $(45.5 \%)$ and a joint $6(3.9 \%)$ that aged between $18-25$ years and $26-35$ years. According to Netha (2011), HR managers focus on bridging the gap between present and future requirements of the company through succession planning initiative organized by the company, which result in younger age group contributes to higher level of companies' performance than the middle or older age group of respondent within the organization. Mutation helps to understand policy implications. It may also be treated as an aspect of experience hence the significance of considering age of respondents. A majority of employees were between $36-43$ years owing to the fact that 
the administration of county government inherited staff from municipal council. Age was considered an important element of the study because it is one of the factors that influence an employee's access to leadership position at a place of work and through this influence implementation of Human Resource Management policies can be understood.

The respondents' level of education was the third item which the study thought is a factor within demographics that can give a direction in correlation to job experience, and also understanding of Human Resource Management policies and practices. Respondents were quizzed to state their educational attainment and the results were as follows;-

Table 4. Frequency distribution for respondents level of education

\begin{tabular}{lcc}
\hline Category & Frequency & Percent \\
\hline Diploma & 30 & 19.9 \\
Bachelor's degree & 72 & 46.8 \\
Master (post graduate) & 43 & 27.9 \\
Doctor of Philosophy & 9 & 5.8 \\
Total & 154 & 100.0 \\
\hline
\end{tabular}

Results from table 4 revealed a majority of employees within the County Government of Kakamega being bachelor's degree holder in different fields as presented with $72(46.8 \%)$ followed by Master degree holders that had $43(27.9 \%)$, diploma holders with $30(19.9 \%)$ and lastly Ph.D. holders with $9(5.8 \%)$. There has never been a consensus reached among researchers on the specific individual factors that influence human resource policies implementation success (Rivkin et al., 2005). Some studies found that employees' experience and educational qualifications significantly influenced implementation of HR policies within organizations (Njeru and Orodho, 2003; Asikhia, 2010; Yala and Wanjohi, 2011; Olaleye, 2011). Moreover, a study done by Adaramola and Obomanu (2011) in Nigeria found that lack of qualified workers led to consistent poor performance of public service in government institutions. Further, the study lastly asked the respondents to state their working positions as tagged with their responsibilities and the results were as follows in table 5;

Table 5. Frequency distribution for respondents position held in County Government of Kakamega

\begin{tabular}{lcc}
\hline Category & Frequency & Percentage \\
\hline County Executive Committee Member & 4 & 2.60 \\
Member of County Assembly & 23 & 12.34 \\
Sub-County Administrator & 3 & 1.95 \\
County Chief Officer & 5 & 3.25 \\
Directors & 9 & 4.55 \\
County Assembly Staff & 23 & 12.34 \\
County Executive Staff & 98 & 62.99 \\
Total & $\mathbf{1 5 4}$ & $\mathbf{1 0 0}$ \\
\hline
\end{tabular}

Result from table 5 indicate that from the responses acquired by the study, $62.9 \%$ of the population were County executive staff, followed by a joint $12.34 \%$ that were Members of the County Assembly and County Assembly staff respectively, $4.6 \%$ that were Directors, 3.25\% that were Chief officers, $2.60 \%$ County Executive committee members and lastly $1.9 \%$ sub-county directors, all being employees within the county government ranks.

\subsubsection{Inspirational Motivation and implementation of Human Resource Management policies}

The objective of the study sought to establish the influence of inspirational motivation on implementation of Human Resource Management policies by Kakamega County Government, Kenya. Data on inspirational motivation and data on implementation of Human Resource Management policies were subjected to descriptive and inferential statistics and findings presented below.

Respondents were asked on their opinions on items within inspirational motivation for factors that include; supervisors talking enthusiastically about what needs to be done; supervisor expressing confidence that goals were achieved; supervisors talking optimistically about the future; supervisor articulating a compelling vision for a department; supervisor creating exciting image of what is essential to consider; supervisor motivating employees and supervisor being a visionary leader. Means and resulting standard deviation measures for statistical description within populations that were obtained were ranked from the most influencing factor to the least and are as shown in table 18 that follow;- 
Table 6: Inspirational Motivation descriptive analysis

\begin{tabular}{lccc}
\hline Indicator & N & Mean & Std. Deviation \\
\hline $\begin{array}{l}\text { respondents' opinion on supervisor talking enthusiastically about what } \\
\text { needs to be done }\end{array}$ & 154 & 3.1 & 1.178 \\
$\begin{array}{l}\text { respondents' opinion on supervisor expressing confidence that goals } \\
\text { will be achieved }\end{array}$ & 154 & 3.1 & 1.172 \\
$\begin{array}{l}\text { respondents' opinion on supervisor's optimism } \\
\text { respondents' opinion on supervisor being a visionary leader }\end{array}$ & 154 & 3.11 & 1.175 \\
$\begin{array}{l}\text { respondents' opinion on supervisor articulating a compelling vision for } \\
\text { the department }\end{array}$ & 154 & 3.1 & 1.165 \\
$\begin{array}{l}\text { respondents' opinion on supervisor creating an exciting image of } \\
\text { essentials }\end{array}$ & 154 & 3.08 & 1.174 \\
respondents' opinion on supervisor motivating employees & 154 & 3.08 & 1.16 \\
\hline
\end{tabular}

From the results, it was established that; opinion on supervisor talking enthusiastically about what needs to be done $(\mathrm{M}=3.10)$; opinion on supervisor expressing confidence that goals will be achieved $(\mathrm{M}=3.10)$; opinion on supervisor's optimism $(\mathrm{M}=3.11)$; opinion on supervisor being a visionary leader $(\mathrm{M}=3.1)$; opinion on supervisor articulating a compelling vision for the department $(\mathrm{M}=3.09)$; opinion on supervisor creating an exciting image of essentials $(M=3.08)$; and opinion on supervisor motivating employees $(M=3.08)$ ranked in their order of influence. From the results, supervisors taking enthusiastically about what needs to be done ranked first with a mean of 3.10 whereas supervisors motivating employees ranked last with a mean of 3.08 within inspirational motivation.

\subsubsection{Inferential statistics on Inspirational Motivation and implementation of Human Resource Management policies}

Inferential statistics were computed for the influence of inspirational motivation on implementation of Human Resource Management policies. Pearson product moment correlation coefficient, regression and ANOVA were computed to establish the direction and strength of influence of inspirational motivation on implementation of Human Resource Management policies in Kakamega County.

Correlation Analysis between inspirational motivation and implementation of Human Resource Management policies was done and results presented in table 7.

Table 7: Correlations for inspirational motivation and implementation of Human Resource Management policies

\begin{tabular}{|c|c|c|c|}
\hline & & $\begin{array}{l}\text { Inspirational } \\
\text { motivation }\end{array}$ & Implementation of HRM Policies \\
\hline Inspirational & Pearson Correlation & 1 & \\
\hline Motivation & Sig. (2-tailed) & & \\
\hline & $\mathrm{N}$ & 154 & \\
\hline Implementation of & Pearson Correlation & $.568^{* *}$ & 1 \\
\hline HRM Policies & Sig. (2-tailed) & .000 & \\
\hline & $\mathrm{N}$ & 154 & 154 \\
\hline
\end{tabular}

**. Correlation is significant at the 0.05 level (2-tailed).

A correlation coefficient statistic that describes the degree of linear association between inspirational motivation and implementation of Human Resource Management policies was performed and study findings revealed that there was a statistically significant positive relationship between inspirational motivation and implementation of Human Resource Management policies in Kakamega county $(r=0.568 ; \mathrm{P}<0.05)$. This implies that the use of inspirational motivation by management at Kakamega County government results in improved implementation of Human Resource Management policies. Findings of this study corroborate findings from other empirical studies on the influence of inspirational motivation on implementation of Human Resource Management policies. Empirical studies by Kelly (2005); Stone, Russell and Patterson (2003) revealed that through the vision, an inspirational leader offers to followers the opportunity to see meaning in their work. Over and above that, followers are challenged with high standards and the leader encourages them to become part of the overall organizational culture and environment. A study by Koech and Namusonge (2012). Revealed that Inspirational motivation puts a vision that inspire and motivates employees since Inspirational motivation leadership refers to leaders who have the ability to inspire and motivate followers. According to findings from a study by Bono and Judge (2004), inspirational leaders have a strong vision for the future based on values and ideals. Here the leader articulates a vision that is appealing and inspiring to followers. Findings from a study by Barbuto (2005) established that due to inspirational motivation, followers are willing to invest more effort in their tasks, feel encouraged and optimistic about the future and believe in their abilities.

Study data relating to inspirational motivation was subjected to regression analysis to predict implementation levels for Human Resource Management policies at the county government of Kakamega and 
findings presented in table 8 .

Table 8: Model Summary for inspirational motivation and implementation of Human Resource Management policies

\begin{tabular}{llllll}
\hline Model & $\mathrm{R}$ & R Square & $\begin{array}{l}\text { Adjusted } \\
\text { Square }\end{array}$ & $\begin{array}{l}\text { R Std. Error of the } \\
\text { Estimate }\end{array}$ & Durbin-Watson \\
\hline 1 & $.315^{\mathrm{a}}$ & .173 & .167 & .86210 & 1.842 \\
\hline
\end{tabular}

a. Predictors: (Constant), Inspirational Motivation

b. Dependent Variable: Implementation of HRM Policies

Study findings in table 8, show that the value of $\mathrm{R}$ squared was 1.173 which implies that inspirational motivation accounted for $17.3 \%$ of the variance in the implementation of Human Resource Management polices at the county government of Kakamega. The study investigated the presence of autocorrelation through calculation of Durbin - Watson statistic. The statistic has to lie between $1.5-2.5$ (Garson, 2012). Durbin Watson coefficient of 1.842 was realised which signified no autocorrelation. Absence of autocorrelation allowed for the use of regression model in their study.

ANOVA was computed to determine how well the model of the study was fitted to predict implementation of Human Resource Management policies and findings presented in table 9.

Table 9: ANOVA for inspirational motivation and implementation of Human Resource Management policies

\begin{tabular}{llrrrrr}
\hline Model & & Sum of Squares & Df & Mean Square & F & Sig. \\
\hline 1 & Regression & 1.499 & 1 & 1.499 & 11.812 & $.000^{\mathrm{b}}$ \\
& Residual & 20.111 & 152 & .132 & & \\
& Total & 21.610 & 153 & & & \\
\end{tabular}

a. Predictors: (Constant), Inspirational motivation

b. Dependent Variable: Implementation of Human Resource Management Policies

ANOVA for the linear model presented in Table 9 inspirational motivation as a predictor for implementation of Human Resource Management polices revealed an $\mathrm{F}$ value $=11.812$ which is significant within $99 \%$ confidence interval with $\mathrm{p}$ value $=0.000$ meaning that the overall model was significant in the prediction of implementation of Human Resource Management policies in Kakamega county.

Table 10: Coefficients for inspirational motivation and implementation of Human Resource Management policies

\begin{tabular}{|c|c|c|c|c|c|c|}
\hline \multirow[b]{2}{*}{ Model } & & \multicolumn{2}{|c|}{ Unstandardized Coefficients } & $\begin{array}{l}\text { Standardized } \\
\text { Coefficients }\end{array}$ & \multirow[b]{2}{*}{$\mathrm{t}$} & \multirow[b]{2}{*}{ Sig. } \\
\hline & & $\mathrm{B}$ & Std. Error & Beta & & \\
\hline 1 & (Constant) & .564 & .085 & & 6.650 & .000 \\
\hline & $\begin{array}{l}\text { Inspirational } \\
\text { motivation }\end{array}$ & .086 & .026 & .263 & 3.366 & .001 \\
\hline
\end{tabular}

a. Dependent Variable: Implementation of Human Resource Management Policies

Results presented in the table show that the unstandardized regression coefficient $(\beta)$ value of implementation of Human Resource Management policies in Kakamega County is 0.086 with a t-value of 3.336 and significance level of $\mathrm{p}=0.001$. This indicated that holding all other factors constant, a unit change in inspirational motivation resulted in 0.086 unit changes in implementation of Human Resource Management polices at the county government of Kakamega. The regression equation to estimate the influence of inspirational motivation on implementation of Human Resource Management policies at the county government of Kakamega can hence be stated as:

$\mathbf{Y}=\mathbf{0 . 5 6 4}+\mathbf{0 . 0 8 6}+\boldsymbol{\varepsilon}$, where $\mathrm{y}$ is implementation of Human Resource Management policies, 0.564 is the constant, 0.086 is the coefficient of determination and $\varepsilon$ is the stochastic error term.

The second hypothesis of the study was;

Inspirational motivation has no statistically significant influence on implementation of Human Resource Management policies by County Government of Kakamega.

Since study findings revealed that inspirational motivation had a statistically significant influence on implementation of Human Resource Management policies by County Government of Kakamega at the level of significance of 0.05 , the null hypothesis is hereby rejected and its alternative adopted.

\subsection{Conclusion}

In light of the study findings, the following conclusion is made;

The objective of the study sought to establish the influence of inspirational motivation on implementation of Human Resource Management policies by Kakamega County Government, Kenya. A correlation coefficient statistic that describes the degree of linear association between inspirational motivation and implementation of 
Human Resource Management policies was performed and study findings revealed that there was a statistically significant positive relationship between inspirational motivation and implementation of Human Resource Management policies in Kakamega county. This result was supported by regression results that revealed a significant prediction power of inspirational motivation on implementation of Human Resource Management policies at the county government of Kakamega. In regard to these findings, it is concluded that inspirational motivation has a statistically significant influence on implementation of Human Resource Management policies by Kakamega County Government, Kenya.

\subsection{Recommendation}

From the findings of the study, it came out clearly that inspirational motivation as a construct of transformational leadership dimensions had a positive statistically significance effect on implementation of Human Resource Management policies by County Government of Kakamega. This study hence recommends that County Government of Kakamega should enhance inspirational motivation by motivating employees and articulating a compelling vision through visionary leadership.

\subsection{Policy Implications}

The study found that inspirational motivation had a positive statistically significant influence on implementation of Human Resource Management policies by County Government of Kakamega. The policy implications arising from this finding are that the significant positive influence of inspirational motivation on implementation of Human Resource Management policies (training and development, reward and discipline) cannot be wished away. The study therefore stretches the frontiers of knowledge on the nexus between transformational leadership and implementation of human resource policies and recommends the adoption of Human Resource Management practices that harness the benefits of transformational leadership at the work places not only at the county government of Kakamega but in Kenya and beyond.

\section{REFERENCES}

Achua, F.C. \& Lussier, R.N. (2007). Effective Leadership. ( $3^{\text {rd }}$ Ed.) U.S.A. Thompson Higher Education.

Adnan, R. and H.H. Mubarak, (2010). Role of Transformational and Tractional leadership on job satisfaction and career satisfaction. Journal of Business and Economic Horizons, 1(1): 29-38.

Armstrong, M. (2007). A Handbook of Employee Reward Management and Practice (2 ${ }^{\text {nd }}$ Ed). Philadelphia; Kogan Page.

Bass, B. M., Avolio, B. J, Jung, D.I. \& Berson, Y. (2003). Predicting unit performance by assessing transformational and Transactional Leadership. Journal of Applied Psychology, 88, 207-218.

Bass, B.M. (2008). The Bass Handbook of Leadership: Theory, Research and Managerial Applications, $4^{\text {th }}$ edition Free Press.

Berman, Paul (1978), “The Study of Macro- and Micro Implementation” Public Policy 26(2), 157-184pp.

Bertrand, Y. (2004). No Ordinary Hero. Madison, WI: Atwood, Prentice Hall

Bono, J.E \& Judge, T.A. (2004). Personality and transformational and transactional leadership: A meta-analysis. Journal of applied psychology, 89 (5), 901-910.

Bourgon, J. (2007). Responsive, Responsible and Respected government: towards a new public Administration theory. International Review of Administrative Sciences, 73(1), 7-26.

Buchanan, D.A. \& Huczynski, A.A (2010). Organizational Behaviour ( $7^{\text {th }}$ Ed). Lombardy, Italy. Pearson Education Ltd.

Burn, S. (2011). What art offers leadership: Looking beneath. In J. D. Barbour \& G. R Hickman (Eds.), Leadership for transformation. San Francisco, CA: Jossey-Bass.

Burns, J.M. (1978). Leadership. New York; Harper \& Row

Burns, N. \& Grove, S. K. (2003). The Practice of Nursing Research: Conduct, Critique and Utilization. Philadelphia: W. Saunders.

Cooper, D.R., \& Schindler, P. S. (2006). Business Research Methods ( $8^{\text {th }}$ Ed.). New Delhi: McGraw - Hill.

Cooper, D.R., \& Schindler, P. S. (2011). Business Research Methods (9 ${ }^{\text {th }}$ Ed.). New York: McGraw - Hill.

County Government Act (2012). The County Government. Nairobi: Government Printer.

Creswell, J.W. (2008). Research Design: Qualitative, Quantitative and Mixed Method Approaches. United Kingdom; Sage Publishers.

Crompton, B. M. (2012). The Effect of Business Coaching and Mentoring on Small to Medium Enterprise Performance and Growth. Manuscript submitted for publication.

De Groot, T., Kiker, D.S. \& Cross, T. C. (2000). A meta-analysis to review organizational outcomes related to charismatic leadership. Canadian journal of administrative sciences 17, 356-371.

Fleming, J. H. \& Asplund, J. (2007). Human Sigma. New York, Gallup Press.

Foster, E. \& Glennester, R. (2009). “Impact of Decentralization on public services; Evidence to date”. In Y. 
Zhou (Ed). Decentralization, Democracy and development: recent experience in Sierra Leone. Washington, DC: World Bank: 73-84.

Geare, A., Edgar, F., \& Deng, M. (2006). Implementation and consumption of Human Resource Management: Stakeholder differences. Research and Practice in Human Resource Management, 14(2), 34-48

Jacobsen, T.B. \& House, S. (2015). The Transformational Leadership Performance in Public and Private Organizations: Identifying Contextual Conditions. Paper presented at International Research Society for Public Management, Birmingham, United Kingdom.

Kasomo, D. (2007). Research Methods in Humanities and Education, Eldorest: Zapf Chancery.

Katou, A.A. (2008). 'Measuring the impact of Human Resource Management on organizational performance". Journal of industrial engineering and management. 2, 119-142.

Kelly, J.M. (2005). The dilemma of the unsatisfied customer in a market model of public administration. Public administration review, 65 (1), 76-84.

Kenya National Bureau of Statistics. (2019). Kenya household survey and poverty index. Nairobi: Government Printer

Kidombo, H. J. (2007). Human resource strategic orientation, firm's commitment and firm performance in large private manufacturing firms in Kenya. Unpublished PhD Thesis, University of Nairobi, Nairobi

Mugenda, A. \& Mugenda, O. (2003). Research Methods: Qualitative and Quantitative Approaches. Nairobi: Acts Press.

Mugenda, A.G. (2008). Social Science Research: Conception, Methodology and Analysis. Nairobi: Applied Research and Training Services.

O 'Toole, J.R. (2003). "Rational Choice and Policy Implementation," America Review of Public Administration. 25(1), 43-57.

Pradeep, D. \& Prabhu, N.R.V (2011). The Relationship between Effective Leadership and Employee Performance. International Conference on Advancements on Information Technology. 20, 198-207.

Rosenbaum, A. (2013). Decentralization and Local Governance: Comparing US and Global Perspectives. Halduskultuur -Administrative Culture, 14(1), 11-17.

Saboe, K.N., Taing, M. U., Way, J.O. \& Johnson. R.E (2015). Examining the unique mediators that underlie the effect of different dimensions of transformational

Tohidi. H \& Mohammad Mehdi Jabbari (2011) 'Modelling of Business Services in Service Oriented Enterprises', Procedia-Computer Science Journal, Vol. 3, pp.1147-1156.

Ulrich, D. \& Smallwood, N. (2010). Leadership Development: Principles that deliver results; The RBL white paper series.

Wong, S., F.Y Millissa \& C. Cheung (2011). Transformational leadership. Leader support, and employee creativity. Leadership \& Organizational Development Journal, 32(7): 656-672.

World Bank, (2015). Building Public Participation in Kenya's Devolved Government CDS paper 1-6 series. Nairobi: Kenya School of Government.

Zhang, J. (2010). The Relationship between Perceived Leadership Styles and Employee Engagement: The Mediating Role of Employee Characteristics. PHD THESIS.

Zungura, M. (2014). Understanding New Public Management within the context of Zimbabwe. International review of social sciences and humanities, 6(2), 246-253. 